Zagazig J. Agric. Res., Vol. 43 No. (5) 2016

http:/www.journals.zu.edu.eg/journalDisplay.aspx?Journalld=1\&queryType=Master

\title{
EVALUATION OF APPLICATION METHODS OF MICRONUTRIENTS (FOLIAR SPRAY, SEED COATING AND SEED SOAKING) ON MAIZE WITH OR WITHOUT COMPOST
}

\author{
Mohamed M. Nabel ${ }^{1}$, Samia H. Ashmaye ${ }^{2}$ and Sara E. Fouda ${ }^{{ }^{*}}$ \\ 1. Soil Sci. Dept., Fac. Agric., Zagazig Univ., Egypt \\ 2. Soil, Water and Environ. Res. Inst., ARC, Giza, Egypt
}

\begin{abstract}
Two field experiments were conducted on maize (Zea mays L. c.v Trible hybrid 310) grown on a newly reclaimed saline clay soil in private farm, Khaled Iben El-Walied, Sahl El-Hussinia, Sharkia Governorate, Egypt, (32 $00 / 00 / /$ to $32^{\circ} 15 / 00 / /$ N Latitude and $30^{\circ} 50 / 00 / /$ to 31 $15 / 00 / /$ E Longitude) in seasons 2014 and 2015. Three micronutrient application methods i.e., foliar spray, seed coating and seed soaking) were evaluated. The nutrients were Fe, $\mathrm{Mn}$ and $\mathrm{Zn}$ mixed in one solution. Rates of the mixture application were 5.0, 10.0 and $15.0 \mathrm{~kg} \mathrm{ha}^{-1}$, respectively. Nutrients application was done solely or in combination with compost, $24 \mathrm{Mg} \mathrm{ha}^{-1}$. Available $\mathrm{N}, \mathrm{P}, \mathrm{K}, \mathrm{Fe}, \mathrm{Mn}$ and $\mathrm{Zn}$ at harvest were increased due to the above mentioned treatments, salinity and $\mathrm{pH}$ were decreased. Micronutrients in combination with compost increased N, P, K, Fe, Mn and Zn uptake by grains. The highest positive response of yield and nutrients uptake by grains was by application of compost in combination with foliar spray of micronutrients followed by seed coating with micronutrients + compost. Highest $\mathrm{N}$ contents and protein yield $674 \mathrm{~kg} \mathrm{ha}^{-1}$ was obtained by foliar spray with $15 \mathrm{~kg}$ nutrient mix ha ${ }^{-1}+$ compost.
\end{abstract}

Key words: Maize, foliar spray, coating, soaking, micronutrients (Fe, Mn and Zn), clay loam soil.

\section{INTRODUCTION}

Maize (Zea mays L.) is an important cereal crop in the world and Egypt and plays a fundamental role and used in human and animal feeding in Egypt (Harris et al., 2007). Total maize grain yield production, in 2010 was 7 million $\mathrm{Mg}$ produced from an area of 920 thousand hectares (El-Gedwy et al., 2012). Its grain is used for manufacturing many products as glucose syrup, starch, corn flakes, oil, lactic acid, gluten. Maize grains contain $72 \%$ starch, $10 \%$ protein, $4.8 \%$ oil, $8.5 \%$ fiber, $3 \%$ sugar and $1 \%$ ash (Zafar-ul-Hye et al., 2014). Yield potential of maize is extremely affected by abiotic stress like salinity, drought, extreme temperature, flooding and extreme irradiation etc. (Lawlor and Cornic, 2002; Akram et al., 2010). Salinity causes numerous physiological and biochemical changes in plants which ultimately reduce yields (Hussain et al., 2013).

Micronutrient deficiency is widespread in plants, animal and humans, (Malakouti, 2008). Micronutrients are required in small amounts and affect photosynthesis, and the other vital processes such as respiration, protein synthesis and reproduction. Many investigators in Egypt reported positive response of many field crops to micronutrient application (Potarzycki and Grzebisz, 2009; Seadh et al., 2009; Kanwal et al., 2010; Zeidan et al., 2010; Salem and ElGizawy, 2012; Siam et al., 2012). Iron is a constituent of many enzymes involved in metabolism and manganese has an essential role in amino acid synthesis by activating of some enzymes particularly decarboxylases and dehydrogenases. Zinc plays an important role in activiting enzymes as superoxide dismutase,

\footnotetext{
*Corresponding author: Tel. : +201096175175

E-mail address: sarafouda_2002@yahoo.com
} 
carbonic anhydrase and RNA polymerase) and a cofactor of enzymes, (RÖmheld and Marchner, 2006).

High salinity affects soils in about 900 thousand ha in Egypt. Most of the saline soils in Egypt are in northern-central Nile Delta. The southern part of El-Hussinia plain, El-Sharkia Governorate, Egypt covering an area of 14160 ha (El-Bordiny and El-Dewiny, 2008).

The current work aimed at evaluating the combined effect of micronutrients applied in different methods solely or in combination with compost on maize.

\section{MATERIALS AND METHODS}

Two field experiments were conducted on maize plants (Zea mays L. c.v Trible hybrid 310) grown on a newly reclaimed saline clay soil in Khaled Iben El-Walied village, Sahl ElHussinia, Sharkia Governorate, Egypt, $\left(32^{\circ}\right.$ 00/00// to $32^{\circ} 15 / 00 / / \mathrm{N}$ Latitude and $30^{\circ} 50 / 00 / /$ to $31^{\circ} 15 / 00 / / \mathrm{E}$ Longitude) during the two seasons of 2014 and 2015 to study the response to application of Fe, Mn and Zn (as a mixture) applied by 3 different methods (foliar, seed coating and seed soaking) at different mixture rates of 5, 10 and $15 \mathrm{~kg} \mathrm{ha}^{-1}$ solely with or without compost, $24 \mathrm{Mg} \mathrm{ha}^{-1}$. The soil texture was clay (Table 1). At the end of experiment soil and plant samples were taken for analyses using methods cited by Chapman and Pratt (1961), Page et al. (1982) and Jackson (1958).

The compost was analyzed, organic matter and nutrients according to methods of Brunner and Wasmer (1978). The obtained results are recorded in Table 2.

\section{Treatments and Experimental Design}

Factorial experiment in randomized complete block design with three replicates was done as follows: (1) method of nutrient application (2) rates of application and (3) compost application. The numbers of treatment combinations were 18 ( 3 methods $\times 3$ rates $\times 2$ compost application. Compost was prepared according to the method of Nasef et al. (2009) crop residues (rice straw, maize stover and faba bean straw). The recommended $\mathrm{N}, \mathrm{P}$ and $\mathrm{K}$ rates were applied to all plots; the rates were 100, 211 and $168 \mathrm{~kg} \mathrm{ha}^{-1}$, respectively. $\mathrm{N}$ was in the form of urea (460 g N $\mathrm{kg}^{-1}$ ), $\mathrm{P}$ was as calcium superphosphate (68g P $\mathrm{kg}^{-1}$ ) and $\mathrm{K}$ was as potassium sulphate (400 $\mathrm{g}$ $\mathrm{kg}^{-1}$ ). The $\mathrm{P}$ fertilizer was broadcasted before ploughing; the $\mathrm{N}$ was applied in three splits, $20 \%$ before sowing, $40 \%$ before the second irrigation (30 days after sowing "DAS") and $40 \%$ before the third irrigation, (45 DAS). The $\mathrm{K}$ was applied in two equal splits after 30 and 45 DAS. Plot area was $50 \mathrm{~m}^{2}(5 \times 10 \mathrm{~m})$ having 14 ridges each of $5 \mathrm{~m}$ in length and $0.7 \mathrm{~m}$ in width, two plants hill ${ }^{-1}$ and $20 \mathrm{~cm}$ between hills. Fe, $\mathrm{Mn}$ and $\mathrm{Zn}$ were in forms of $\mathrm{FeSO}_{4}, \mathrm{MnSO}_{4}$ and $\mathrm{ZnSO}_{4}$ having $\mathrm{Fe}, \mathrm{Mn}$ and $\mathrm{Zn}$ mixture of $120 \mathrm{~g}$ $\mathrm{kg}^{-1}$ and applied at three rates i.e., 5, 10 and 15 $\mathrm{kg} \mathrm{ha}^{-1}$. The application methods were foliar spray; seed coating and seed soaking into nutrient solution. Foliar spray was applied 40 DAS at a rate of $1000 \mathrm{l} \mathrm{ha}^{-1}$, seed coating was done by mixing the amount of fertilizer salt needed per plot with a sticky material and the appropriate weight of seeds so as to make cating of the fertilizer around the seeds. Soaking was done by dissolving the proper amount of fertilizer in water, then soaking the proper amount of seeds into the solution for $12 \mathrm{hr}$., following soaking. Solution remaining after soaking was sprayed over the soil of the soaking treatments.

\section{Crop Management Practices}

Maize (Triple hybrid, $310 \mathrm{cv}$ ) was provided by Maize Department, Field Crop Institute. ARC. Seeding at a rate of $34 \mathrm{~kg} \mathrm{ha}^{-1}$, performed on $25^{\text {th }}$ April for 2014 season and $20^{\text {th }}$ for April 2015 season. Two to three seeds were sown per hill, and then 30 days after seeding plants were thinned to one plant per hill. The crop was irrigated with water of El-Salam Canal (Agricultural drainage water mixed with Nile water at a 1:1 ratio). Some chemical properties of the irrigation water as described are shown in Table 3.

To control soil salinity, water was applied immediately after sowing for 4 hours then excess water was drained. The same process was repeated in the second day. After that, irrigation water was added every 15 days until the end of the growing seasons. Agricultural practices for growing maize were carried out as recommended by the Ministry of Agriculture. 
Table 1. Physical and chemical properties of the investigated soil

\begin{tabular}{|c|c|c|c|c|c|}
\hline \multicolumn{3}{|c|}{ Property } & Value & Property & Value \\
\hline \multicolumn{3}{|c|}{ Particle size distribution (\%) } & \multicolumn{3}{|c|}{ Soluble ions (mmolc $\left.\mathrm{l}^{-1}\right)$} \\
\hline \multicolumn{3}{|l|}{ - Clay } & 45.88 & - $\mathrm{Na}^{+}$ & 58.86 \\
\hline \multicolumn{3}{|l|}{ - Silt } & 23.31 & $\cdot \mathbf{K}^{+}$ & 1.49 \\
\hline \multicolumn{3}{|l|}{ - Sand } & 30.81 & - $\mathrm{Ca}^{++}$ & 9.56 \\
\hline \multicolumn{3}{|c|}{ - Textural class } & Clay & - $\mathbf{M g}^{++}$ & 13.00 \\
\hline \multicolumn{3}{|c|}{ - EC $\left(\mathrm{dSm}^{-1}\right)$ in soil paste extract } & 8.34 & - $\mathrm{Cl}^{-}$ & 37.06 \\
\hline \multicolumn{3}{|c|}{ - pH [Soil suspension 1:2.5] } & 8.04 & - $\mathrm{HCO}_{3}^{-}$ & 8.22 \\
\hline \multicolumn{3}{|c|}{ - Organic matter ( $\left.\mathrm{g} \mathrm{kg}^{-1}\right)$} & 5.41 & - $\mathrm{SO}_{4}{ }^{=}$ & 37.63 \\
\hline \multicolumn{3}{|l|}{ - SAR } & 17.20 & - $\mathrm{CaCO}_{3}\left(\mathrm{~g} \mathrm{~kg}^{-1}\right)$ & 64.9 \\
\hline \multicolumn{3}{|l|}{ - } & & - ESP & 21.03 \\
\hline \multicolumn{6}{|c|}{ Available macro and micronutrients ( $\mathrm{mg} \mathrm{kg}^{-1}$ soil) } \\
\hline $\mathbf{N}$ & $\mathbf{P}$ & $\mathbf{K}$ & $\mathbf{F e}$ & Mn & \\
\hline 35.27 & 3.89 & 175 & 2.40 & 3.15 & \\
\hline
\end{tabular}

Table 2. Chemical properties of the used compost

\begin{tabular}{|c|c|c|c|c|c|c|c|c|c|c|c|}
\hline \multirow{2}{*}{$\begin{array}{c}\text { Moisture } \\
\text { (\%) }\end{array}$} & \multirow{2}{*}{$\begin{array}{l}\text { OM } \\
(\%)\end{array}$} & \multirow{2}{*}{$\begin{array}{l}\text { OC } \\
\text { (\%) }\end{array}$} & \multirow{2}{*}{$\begin{array}{l}\mathrm{C} / \mathrm{N} \\
\mathbf{( \% )}\end{array}$} & \multicolumn{3}{|c|}{ Macronutrients (\%) } & \multicolumn{3}{|c|}{ Micronutrients (mg/kg) } & \multirow[t]{2}{*}{$\mathbf{p H}$} & \multirow{2}{*}{$\begin{array}{c}\mathrm{EC}\left(\mathrm{dSm}^{-1}\right) \\
(1: 10)\end{array}$} \\
\hline & & & & $\overline{\mathbf{N}}$ & $\overline{\mathbf{P}}$ & $\bar{K}$ & $\overline{F e}$ & Mn & $\overline{Z n}$ & & \\
\hline $25-30$ & 55.34 & 32.10 & 13.38 & 2.40 & 0.69 & 2.69 & 127.52 & 76.22 & 31.50 & 7.42 & 3.85 \\
\hline
\end{tabular}

Table 3. Chemical analysis of irrigation water at El-Salam canal

\begin{tabular}{|c|c|c|c|c|c|c|c|c|}
\hline \multirow[t]{2}{*}{ pH } & \multirow[t]{2}{*}{$\mathrm{EC}\left(\mathrm{dSm}^{-1}\right)$} & \multicolumn{4}{|c|}{ Macronutrients $\left(\mathrm{mgl}^{-1}\right)$} & \multicolumn{3}{|c|}{ Micronutrients $\left(\mathrm{mgl}^{-1}\right)$} \\
\hline & & $\mathrm{NO}_{3}-\mathrm{N}$ & $\mathrm{NH}_{4}-\mathrm{N}$ & $\mathbf{P}$ & $\bar{K}$ & $\mathbf{F e}$ & Mn & $\mathbf{Z n}$ \\
\hline 8.03 & 1.95 & 14.60 & 8.00 & 3.10 & 7.19 & 2.14 & 1.09 & 0.078 \\
\hline
\end{tabular}




\section{Measured Parameters}

Plant height was measured after 75 days after seeding (average of 10 plants). During growth time the followings were recorded on 10 plants taken at random: ear weight, grain weight per ear, 100-grain weight, stover yield, and grain yield, (adjusted to 15\% moisture content). Plant samples were washed with water then dried at $70^{\circ} \mathrm{C}$ for $48 \mathrm{hr}$. Then milled and analyzed for nutrients, digestion with mixture of concentrated $\mathrm{H}_{2} \mathrm{SO}_{4}$ and $\mathrm{HClO}_{4}$ acids. $\mathrm{N}$ was determined by micro-kjeldahl according to AOAC (1990). While $\mathrm{P}$ was determined using ascorbic acid method and $\mathrm{K}$ was determined by a flame photometer (Chapman and Pratt, 1961). Fe, Mn and $\mathrm{Zn}$ were determined using the atomic absorption (model GBC 932). Protein content was calculated by multiplying grain $\mathrm{N}$ by 6.25 (FAO, 2003).

\section{Statistical Analysis}

Data (combined of the two seasons) were statistically analyzed according to MSTAT-C, Statistical Software Package according to Gomez and Gomez (1984).

\section{RESULTS AND DISCUSSION}

\section{Soil Properties After Harvest}

\section{Soil pH and EC}

The data representing the effect of application of micronutrients and compost, on soil $\mathrm{pH}$ and EC are presented in Table 4. Values in combined data of the two studied seasons show that, soil $\mathrm{pH}$ was slightly decreased and ranged between 7.94-8.01 without compost and 7.92-8.00 with compost. The highest decrease in $\mathrm{pH}$ was observed when micronutrients added as foliar spray at the high rate in combination with compost. This is an indication of effect of microorganisms on decomposing organic matter releasing organic acids and producing several phytohormones such as indole acetic acid and cytokinins (El-Galad et al., 2013). A decrease in pH was observed by Sarwar et al. (2010) upon applying organic manure. They observed production of organic acids (amino acids, glycine, cystein and humic acids) during mineralization of the organic manure.
Soil salinity decreased by the treatment. The lowest EC values of 4.89 and $3.94 \mathrm{dSm}^{-1}$ occurred when the plants were sprayed with micronutrients at high rate, with decreases of $41.4 \%$ without compost and $43.2 \%$ with compost, lowering of soil $\mathrm{pH}$ by the compost and in turn encouraging must have enhanced the availability of plant nutrients, leading to a decrease in EC.

Clay domains are coated with the released active organic acids, and then forming coarse sizes of water stable aggregates would form upon decreasing EC leading to improved filteration and accelerating leaching of soluble salts (Ewees and Abdel-Hafeez, 2010). Improved aggregation by would increase water permeability and encourage downward movement of water carrying Na-salts out of the soils (Bassiony and Shaban, 2010 ; Rashed et al., 2011).

\section{Available N, P and $\mathbf{K}$ Macronutrients in the Soil After Harvest}

Table 5 reveals that the application of micronutrients with different methods and rates in presence or absence of compost showed greater $\mathrm{N}, \mathrm{P}$ and $\mathrm{K}$ contents than the contents at the start of the experiment. The treatment of the high foliar spray combined with compost gave the highest contents. The positive effect of compost is an indication of its mineralization (Bhandari et al., 2002) and (Yadvinder et al., 2004). Formation of organic acids during degradation of organic material as a function of the microbial activities which in turn produce chelating materials, leading to increased availability of elements in the rhizosphere (Wenhui et al., 2010 ; Taha et al., 2010).

Application of micronutrients at the high rate increased soil available $\mathrm{N}, \mathrm{P}$ and $\mathrm{K}$ by averages 4.7, 15.9 and $8.0 \%$ over those given by the low application rate indicating a considerable positive effect of micronutrients on available $\mathrm{P}$ in particular. The foliar method of application showed the highest positive effect followed by the soaking method, then the coating method.

\section{Available Fe, Mn and Zn Micronutrients in the Soil After Harvest}

Table 6 shows that available Fe, Mn and Zn followed the same trend of that observed for macronutrients. Application of micronutrients at 
Table 4. Soil pH and EC after harvest as affected by treatments

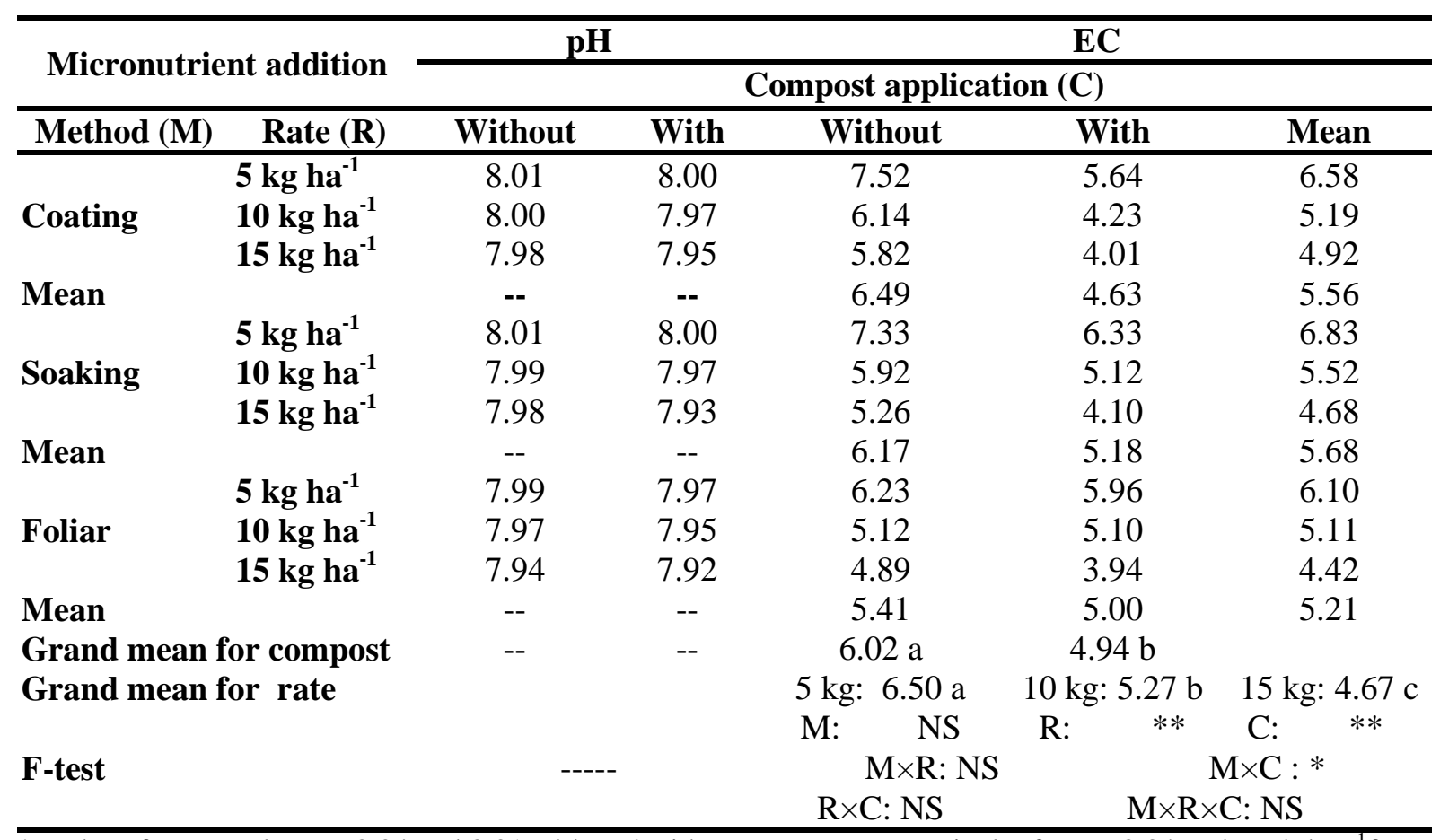

* Values for control were, 8.04 and 8.01 with and without compost respectively, for $\mathrm{pH} 8.34$ and $6.94 \mathrm{dsm}^{-1}$ for EC with and without compost, respectively.

* Different lower case letters indicate statistically significant differences between treatments $(\mathrm{P} \leq 0.05)$.

Table 5. Available macronutrient contents $\left(\mathrm{mg} \mathrm{kg}^{-1}\right)$ in soil after harvest

\begin{tabular}{|c|c|c|c|c|c|c|c|c|c|c|}
\hline \multirow{3}{*}{\multicolumn{2}{|c|}{ Micronutrient addition }} & \multicolumn{9}{|c|}{ Available macronutrients (mg kg ${ }^{-1}$ ) } \\
\hline & & \multicolumn{3}{|c|}{$\mathbf{N}$} & \multicolumn{3}{|c|}{$\mathbf{P}$} & \multicolumn{3}{|c|}{$\mathbf{K}$} \\
\hline & & \multicolumn{9}{|c|}{ Compost application (C) } \\
\hline Method (M) & Rate (R) & Without & With & Mean & Without & With & Mean & Without & With & Mean \\
\hline \multirow{3}{*}{ Coating } & $5 \mathrm{~kg} \mathrm{ha}^{-1}$ & 38.1 & 40.2 & 39.2 & 4.10 & 4.18 & 4.14 & 195 & 197 & 196 \\
\hline & $10 \mathrm{~kg} \mathrm{ha}^{-1}$ & 38.7 & 41.0 & 39.9 & 4.52 & 4.66 & 4.59 & 198 & 203 & 201 \\
\hline & $15 \mathrm{~kg} \mathrm{ha}^{-1}$ & 40.2 & 41.2 & 40.7 & 4.95 & 4.99 & 4.97 & 201 & 207 & 204 \\
\hline \multirow[t]{2}{*}{ Mean } & & 39.0 & 40.8 & 39.9 c & 4.52 & 4.61 & 4.57 & 198 & 202 & $200 \mathrm{~b}$ \\
\hline & $5 \mathrm{~kg} \mathrm{ha}^{-1}$ & 38.9 & 41.0 & 40.0 & 4.08 & 4.16 & 4.12 & 198 & 203 & 201 \\
\hline \multirow[t]{2}{*}{ Soaking } & $10 \mathrm{~kg} \mathrm{ha}^{-1}$ & 40.2 & 41.6 & 40.9 & 4.15 & 4.89 & 4.52 & 203 & 215 & 209 \\
\hline & $15 \mathrm{~kg} \mathrm{ha}^{-1}$ & 42.5 & 42.3 & 42.4 & 4.20 & 5.02 & 4.61 & 208 & 220 & 214 \\
\hline \multirow[t]{2}{*}{ Mean } & & 40.5 & 41.6 & $41.1 \mathrm{~b}$ & 4.14 & 4.69 & 4.42 & 203 & 213 & $208 \mathrm{~b}$ \\
\hline & $5 \mathrm{~kg} \mathrm{ha}^{-1}$ & 41.1 & 42.2 & 41.7 & 4.15 & 4.39 & 4.27 & 199 & 213 & 206 \\
\hline \multirow[t]{2}{*}{ Foliar } & $10 \mathrm{~kg} \mathrm{ha}^{-1}$ & 41.9 & 43.7 & 42.8 & 4.36 & 4.95 & 4.66 & 209 & 226 & 218 \\
\hline & $15 \mathrm{~kg} \mathrm{ha}^{-1}$ & 43.0 & 44.0 & 43.5 & 4.85 & 5.05 & 4.95 & 218 & 248 & 233 \\
\hline \multirow{2}{*}{\multicolumn{2}{|c|}{$\begin{array}{l}\text { Mean } \\
\text { Grand mean for (C) }\end{array}$}} & 42.0 & 43.3 & $42.6 \mathrm{a}$ & 4.45 & 4.80 & 4.63 & 209 & 229 & 219 a \\
\hline & & 40.5 & 41.9 & & 4.37 & 4.70 & & $203 \mathrm{~b}$ & $215 \mathrm{a}$ & \\
\hline \multirow{2}{*}{\multicolumn{2}{|c|}{ Grand mean for (R) }} & $5 \mathrm{~kg}:$ & 10 kg: & 15 kg: & 5 kg: & $10 \mathrm{~kg}:$ & $15 \mathrm{~kg}:$ & 5 kg: & 10 kg: & 15 kg: \\
\hline & & $40.3 \mathrm{c}$ & $41.2 \mathrm{~b}$ & $42.2 \mathrm{a}$ & $4.18 \mathrm{~b}$ & $4.59 \mathrm{a}$ & $4.84 \mathrm{a}$ & $201 \mathrm{~b}$ & $209 a b$ & 217 a \\
\hline \multirow{3}{*}{ F-test } & & $\mathrm{M}: \quad * *$ & $\mathrm{R}: * *$ & C: NS & M: NS & $\mathrm{R}: * *$ & C: NS & $\mathrm{M}: \quad * *$ & $\mathrm{R}: * *$ & $\mathrm{C}: * *$ \\
\hline & & $\mathrm{M} \times \mathrm{R}: \mathrm{NS}$ & $\mathrm{M} \times \mathrm{C}$ & & $\mathrm{M} \times \mathrm{R}: \mathrm{NS}$ & \multirow{2}{*}{\multicolumn{3}{|c|}{$\begin{array}{lll}S & M \times C: N S \quad M \times R: N S \\
M \times R \times C: N S R \times C: N S\end{array}$}} & \multirow{2}{*}{\multicolumn{2}{|c|}{$\begin{array}{l}\mathrm{M} \times \mathrm{C}: \mathrm{NS} \\
\mathrm{M} \times \mathrm{R} \times \mathrm{C}: \mathrm{NS}\end{array}$}} \\
\hline & & $\mathrm{R} \times \mathrm{C}: \mathrm{NS}$ & $M \times R$ & $\times \mathrm{C}: \mathrm{NS}$ & $\mathrm{R} \times \mathrm{C}: \mathrm{NS}$ & & & & & \\
\hline
\end{tabular}


Table 6. Available micronutrient contents $\left(\mathrm{mg} \mathrm{kg}^{-1}\right)$ in soil after harvest

\begin{tabular}{|c|c|c|c|c|c|c|c|c|c|c|}
\hline \multirow{2}{*}{\multicolumn{2}{|c|}{ Micronutrient addition }} & \multicolumn{9}{|c|}{ Available macronutrients (mg kg $\left.{ }^{-1}\right)$} \\
\hline & & \multicolumn{3}{|c|}{$\overline{F e}$} & \multicolumn{3}{|c|}{ Mn } & \multicolumn{3}{|c|}{$\overline{Z n}$} \\
\hline & & \multicolumn{9}{|c|}{ Compost application (C) } \\
\hline Method (M) & Rate (R) & Without & With & Mean & Without & With & Mean & Without & With & Mean \\
\hline \multirow{3}{*}{ Coating } & $5 \mathrm{~kg} \mathrm{ha}^{-1}$ & 3.03 & 3.34 & 3.19 & 1.42 & 1.66 & 1.54 & 0.69 & 0.78 & 0.74 \\
\hline & 10 kg ha $^{-1}$ & 3.12 & 3.45 & 3.29 & 1.44 & 1.78 & 1.61 & 0.71 & 0.83 & 0.77 \\
\hline & $15 \mathrm{~kg} \mathrm{ha}^{-1}$ & 3.22 & 3.52 & 3.37 & 1.68 & 1.82 & 1.75 & 0.76 & 0.85 & 0.81 \\
\hline \multirow[t]{2}{*}{ Mean } & & 3.12 & 3.44 & $3.28 \mathrm{~b}$ & 1.51 & 1.75 & 1.63 & 0.72 & 0.82 & 0.77 \\
\hline & $5 \mathrm{~kg} \mathrm{ha}^{-1}$ & 3.14 & 3.44 & 3.29 & 1.55 & 1.75 & 1.65 & 0.72 & 0.86 & 0.79 \\
\hline \multirow[t]{2}{*}{ Soaking } & $10 \mathrm{~kg} \mathrm{ha}^{-1}$ & 3.18 & 3.69 & 3.44 & 1.69 & 1.85 & 1.77 & 0.75 & 0.89 & 0.82 \\
\hline & $15 \mathrm{~kg} \mathrm{ha}^{-1}$ & 3.33 & 3.72 & 3.53 & 1.75 & 1.88 & 1.82 & 0.78 & 0.92 & 0.85 \\
\hline \multirow[t]{2}{*}{ Mean } & & 3.22 & 3.62 & 3.42 b & 1.66 & 1.83 & 1.75 & 0.75 & 0.89 & 0.82 \\
\hline & $5 \mathrm{~kg} \mathrm{ha}^{-1}$ & 3.85 & 3.48 & 3.67 & 1.89 & 1.79 & 1.84 & 0.78 & 0.88 & 0.83 \\
\hline \multirow[t]{2}{*}{ Foliar } & $10 \mathrm{~kg} \mathrm{ha}^{-1}$ & 3.94 & 3.74 & 3.84 & 1.96 & 1.89 & 1.93 & 0.82 & 0.96 & 0.89 \\
\hline & 15 kg ha $^{-1}$ & 3.98 & 3.83 & 3.91 & 1.99 & 1.93 & 1.96 & 0.86 & 0.98 & 0.92 \\
\hline \multirow{2}{*}{\multicolumn{2}{|c|}{$\begin{array}{l}\text { Mean } \\
\text { Grand mean for }(C)\end{array}$}} & 3.92 & 3.68 & 3.81 a & 1.95 & 1.87 & 1.91 & 0.82 & 0.94 & 0.88 \\
\hline & & 3.42 & 3.58 & & 1.71 & 1.82 & & 0.76 & 0.88 & \\
\hline \multirow{2}{*}{\multicolumn{2}{|c|}{ Grand mean for $(R)$}} & 5 kg: & 10 kg: & 15 kg: & $5 \mathrm{~kg}:$ & 10 kg: & 15 kg: & 5 kg: & 10 kg: & 15 kg: \\
\hline & & 3.38 & 3.52 & 3.60 & 1.68 & 1.77 & 1.84 & 0.79 & 0.83 & 0.86 \\
\hline & & M: $\quad *$ & $\mathrm{R}: \mathrm{NS}$ & C: NS & \multicolumn{3}{|c|}{ M: NS R: NS C: NS } & \multicolumn{3}{|c|}{ M: NS R: NS C: NS } \\
\hline \multirow{2}{*}{\multicolumn{2}{|c|}{ F-test }} & $\mathrm{M} \times \mathrm{R}: \mathrm{NS}$ & \multicolumn{2}{|c|}{$\mathrm{M} \times \mathrm{C}: \mathrm{NS}$} & $\mathrm{M} \times \mathrm{R}: \mathrm{N} S$ & \multirow{2}{*}{\multicolumn{2}{|c|}{$\begin{array}{c}M \times C: N S \\
M \times R \times C: N S\end{array}$}} & \multicolumn{3}{|c|}{$M \times R: N S \quad M \times C$ : NS } \\
\hline & & $\mathrm{R} \times \mathrm{C}: \mathrm{NS}$ & \multicolumn{2}{|c|}{$\mathrm{M} \times \mathrm{R} \times \mathrm{C}: \mathrm{NS}$} & $\mathrm{R} \times \mathrm{C}: \mathrm{NS}$ & & & $\mathrm{R} \times \mathrm{C}: \mathrm{N}$ & \multicolumn{2}{|c|}{$\begin{array}{c}\mathrm{M} \times \mathrm{C}: \mathrm{NS} \\
\mathrm{M} \times \mathrm{R} \times \mathrm{C}: \mathrm{NS}\end{array}$} \\
\hline
\end{tabular}

different rates in presence or absence of compost caused higher contents of $\mathrm{Fe}, \mathrm{Mn}$ and $\mathrm{Zn}$ compared with the contents at start of the experiment (Table 1). Increased application of micronutrients was accompanied by increased contents of available micronutrients. The high rate of micronutrient application showed more available $\mathrm{Fe}, \mathrm{Mn}$ and $\mathrm{Zn}$ by average of 6.5, 9.5 and $8.9 \%$, respectively over contents of the low application rate. The effect was marked with $\mathrm{Fe}$ in particular. El-Galad et al. (2013) reported that application of compost was effective in increasing the release of $\mathrm{Fe}, \mathrm{Mn}$ and $\mathrm{Zn}$ into the growing media. The highest available Fe of 3.98 $\mathrm{mg} \mathrm{kg}{ }^{-1}$ and $\mathrm{Mn}$ of $1.99 \mathrm{mg} \mathrm{kg}^{-1}$ and $\mathrm{Zn}$ of 0.98 $\mathrm{mg} \mathrm{kg}{ }^{-1}$ was obtained by the highest foliar spray rate with compost.

There was a superiority of the foliar spray than the coating or soaking methods in increasing available $\mathrm{Fe}, \mathrm{Mn}$ and $\mathrm{Zn}$. Application of compost enhanced the availability of micronutrients in soil especially Zn while, for Fe and Mn, coating and soaking had a positive effect. Decomposition of organic matter from compost as well as the soil (Ewees and AbdelHafeez, 2010). The average positive effect of the addition rates of micronutrients on available $\mathrm{Fe}$, $\mathrm{Mn}$ and $\mathrm{Zn}$ could be arranged in the following order: high rate $>$ medium rate $>$ low rate.

\section{Growth and Yield Productivity of Maize}

The effects of micronutrients and compost treatments on plant height, ear weight and grain weight/ ear are given in Table 7. The effects show increased values with the increase in the rate of micronutrient application. The highest values of $219 \mathrm{~cm}, 268 \mathrm{~g}$ and $262 \mathrm{~g}$ for plant height, ear weight and grain weight per ear, respectively (increases of 17, 12 and 12\%, respectively) were recorded in the plants treated with foliar spray combined with compost. The lowest respective values of $182 \mathrm{~cm}, 238 \mathrm{~g}$ and $234 \mathrm{~g}$ were obtained by plants receiving the low coating method uncombined with compost. 
Table 7. Some yield attributes of maize as affected by treatments

\begin{tabular}{|c|c|c|c|c|c|c|c|c|c|c|}
\hline \multicolumn{2}{|c|}{ Micronutrient addition } & \multicolumn{3}{|c|}{ Plant height (cm) } & \multicolumn{3}{|c|}{ Weight of ear (g) } & \multicolumn{3}{|c|}{ Grain weight/ear (g) } \\
\hline & & \multicolumn{9}{|c|}{ Compost application (C) } \\
\hline \multirow[t]{2}{*}{ Method (M) } & Rate (R) & Without & With & Mean & Without & With & Mean & Without & With & Mean \\
\hline & $5 \mathrm{~kg} \mathrm{ha}^{-1}$ & 182 & 195 & 189 & 238 & 246 & 242 & 234 & 240 & 237 \\
\hline \multirow[t]{2}{*}{ Coating } & $10 \mathrm{~kg} \mathrm{ha}^{-1}$ & 185 & 199 & 192 & 243 & 252 & 248 & 240 & 247 & 244 \\
\hline & $15 \mathrm{~kg} \mathrm{ha}^{-1}$ & 188 & 203 & 196 & 248 & 258 & 253 & 246 & 254 & 250 \\
\hline \multirow[t]{2}{*}{ Mean } & & 185 & 199 & 192 b & 243 & 252 & $248 \mathrm{~b}$ & 240 & 247 & 244 \\
\hline & $5 \mathrm{~kg} \mathrm{ha}^{-1}$ & 186 & 197 & 192 & 245 & 255 & 250 & 239 & 250 & 245 \\
\hline \multirow[t]{2}{*}{ Soaking } & $10 \mathrm{~kg} \mathrm{ha}^{-1}$ & 191 & 204 & 198 & 254 & 258 & 256 & 250 & 253 & 252 \\
\hline & $15 \mathrm{~kg} \mathrm{ha}^{-1}$ & 197 & 212 & 205 & 259 & 263 & 261 & 254 & 258 & 256 \\
\hline \multirow[t]{2}{*}{ Mean } & & 191 & 204 & 198 b & 253 & 259 & $256 a b$ & 248 & 254 & 251 \\
\hline & $5 \mathrm{~kg} \mathrm{ha}^{-1}$ & 194 & 201 & 198 & 248 & 259 & 254 & 243 & 254 & 249 \\
\hline \multirow[t]{2}{*}{ Foliar } & $10 \mathrm{~kg} \mathrm{ha}^{-1}$ & 198 & 214 & 206 & 257 & 264 & 261 & 253 & 259 & 256 \\
\hline & $15 \mathrm{~kg} \mathrm{ha}^{-1}$ & 206 & 219 & 213 & 263 & 268 & 266 & 260 & 262 & 261 \\
\hline \multicolumn{2}{|l|}{ Mean } & 199 & 211 & 205 a & 256 & 264 & $260 \mathrm{a}$ & 252 & 258 & 255 \\
\hline \multicolumn{2}{|c|}{ Grand mean for $(C)$} & $192 \mathrm{~b}$ & 205 a & & $251 \mathrm{~b}$ & $258 \mathrm{a}$ & & 247 & 253 & \\
\hline \multirow{2}{*}{\multicolumn{2}{|c|}{ Grand mean for $(R)$}} & 5 kg: & 10 kg: & 15 kg: & $5 \mathrm{~kg}:$ & 10 kg: & 15 kg: & $5 \mathrm{~kg}$ : & 10 kg: & 15 kg: \\
\hline & & $193 \mathrm{~b}$ & $199 \mathrm{ab}$ & $204 \mathrm{a}$ & $249 \mathrm{~b}$ & $255 \mathrm{ab}$ & $260 \mathrm{a}$ & 243 & 250 & 256 \\
\hline \multirow{3}{*}{ F-test } & & $\mathrm{M}: \quad * *$ & $\mathrm{R}: * *$ & $\mathrm{C}: * *$ & M: & $\mathrm{R}: *$ & $\mathrm{C}: *$ & M: NS & R: NS & C: NS \\
\hline & & $\mathrm{M} \times \mathrm{R}: \mathrm{NS}$ & $\mathrm{M} \times \mathrm{C}$ & NS & $\mathrm{M} \times \mathrm{R}: \mathrm{NS}$ & $\mathrm{M} \times \mathrm{C}$ & NS & $\mathrm{M} \times \mathrm{R}: \mathrm{NS}$ & $M \times$ & C: NS \\
\hline & & $\mathrm{R} \times \mathrm{C}: \mathrm{NS}$ & $\mathrm{M} \times \mathrm{R}$ & $\times \mathrm{C}: \mathrm{NS}$ & $\mathrm{R} \times \mathrm{C}: \mathrm{NS}$ & $\mathrm{M} \times \mathrm{R}$ & $\times \mathrm{C}: \mathrm{NS}$ & $\mathrm{R} \times \mathrm{C}: \mathrm{NS}$ & $M \times$ & $\mathrm{R} \times \mathrm{C}: \mathrm{NS}$ \\
\hline
\end{tabular}

The beneficial effect of compost on maize growth is a demonstration of the improvement which must have occurred to the conditions; lowering $\mathrm{pH}$ and forming organic matter in the root rhizosphere enhancing nutrient by roots (Helmy and Shaban, 2008).

Application of micronutrients showed that the foliar spray gave the highest values while the coating method gave the lowest values. The high rate of application showed the highest values followed by the medium rate then low rate.

\section{0-Grain Weight, Stover and Grain Yields}

The data of 100-grain weight, stover and grain yield of maize plants are presented in Table 8 . The obtained results show increases due to application of micronutrients at different methods and rates as well as compost addition.

As for 100-grain weight, foliar spray gave highest values with or without compost. Foliar application with micronutrients was reported by (Hythum and Nasser, 2012) to be more effective than the other methods. The positive response to compost reflects it improvement of the nutritional status of maize plants which in turn was positively reflected on the grain yield (Shaban et al., 2011). The highest value of 32.4 $\mathrm{g}$ for 100-grain weight was recorded for the plants treated with foliar spray at high rate combined with compost giving an increase of $23.7 \%$ over the control. Increasing the rates of micronutrients, significantly increased 100 -grain weight of maize and could be arranged in an ascending order, as follow: $15 \mathrm{~kg} \mathrm{ha}^{-1}>10 \mathrm{~kg}$ $\mathrm{ha}^{-1}>5 \mathrm{~kg} \mathrm{ha}^{-1}$.

Regarding stover and grain yields of maize, foliar spray gave the highest values when combined with compost. These results are in harmony with those which obtained by Potarzycki and Grzebisz (2009) as well as Hythum and Nasser (2012). Bakry et al. (2009) applied micronutrients to maize grown on a sandy 
Table 8. 100-grain weight and maize yields as affected by treatments

\begin{tabular}{|c|c|c|c|c|c|c|c|c|c|c|}
\hline \multirow{2}{*}{\multicolumn{2}{|c|}{ Micronutrient addition }} & \multicolumn{3}{|c|}{ 100-grain weight (g) } & \multicolumn{3}{|c|}{ Stover yield (ton ha ${ }^{-1}$ ) } & \multicolumn{3}{|c|}{ Grain yield (ton ha ${ }^{-1}$ ) } \\
\hline & & \multicolumn{9}{|c|}{ Compost application (C) } \\
\hline \multirow[t]{2}{*}{ Method (M) } & Rate (R) & Without & With & Mean & Without & With & Mean & Without & With & Mean \\
\hline & $5 \mathrm{~kg} \mathrm{ha}^{-1}$ & 26.6 & 27.7 & 27.2 & 5.46 & 5.86 & 5.66 & 4.73 & 5.58 & 5.15 \\
\hline \multirow[t]{2}{*}{ Coating } & $10 \mathrm{~kg} \mathrm{ha}^{-1}$ & 27.4 & 28.9 & 28.2 & 5.58 & 6.09 & 5.83 & 5.04 & 5.80 & 5.44 \\
\hline & $15 \mathrm{~kg} \mathrm{ha}^{-1}$ & 28.1 & 29.6 & 28.9 & 5.63 & 6.20 & 5.92 & 5.21 & 5.95 & 5.58 \\
\hline \multirow[t]{2}{*}{ Mean } & & 27.4 & 28.8 & $28.1 \mathrm{~b}$ & 1.96 & 5.55 & 6.06 & 5.80 & 16.42 & 5.78 \\
\hline & $5 \mathrm{~kg} \mathrm{ha}^{-1}$ & 27.1 & 28.9 & 28.0 & 5.52 & 6.06 & 5.79 & 4.78 & 5.63 & 5.21 \\
\hline \multirow[t]{2}{*}{ Soaking } & $10 \mathrm{~kg} \mathrm{ha}^{-1}$ & 27.7 & 29.3 & 28.5 & 5.89 & 6.31 & 6.10 & 5.24 & 6.09 & 5.66 \\
\hline & $15 \mathrm{~kg} \mathrm{ha}^{-1}$ & 28.3 & 30.0 & 29.2 & 6.03 & 6.43 & 6.23 & 5.61 & 6.20 & 5.92 \\
\hline \multirow[t]{2}{*}{ Mean } & & 27.7 & 29.4 & $28.6 \mathrm{~b}$ & 2.05 & 5.80 & 6.26 & 6.03 & 17.07 & 5.97 \\
\hline & $5 \mathrm{~kg} \mathrm{ha}^{-1}$ & 28.1 & 29.9 & 29.0 & 5.86 & 6.45 & 6.16 & 5.01 & 6.03 & 5.52 \\
\hline \multirow[t]{2}{*}{ Foliar } & $10 \mathrm{~kg} \mathrm{ha}^{-1}$ & 28.9 & 31.3 & 30.1 & 6.17 & 6.54 & 6.36 & 5.63 & 6.45 & 6.06 \\
\hline & $15 \mathrm{~kg} \mathrm{ha}^{-1}$ & 29.0 & 32.4 & 30.7 & 6.37 & 6.94 & 6.65 & 5.86 & 6.51 & 6.20 \\
\hline \multicolumn{2}{|l|}{ Mean } & 28.6 & 31.2 & 29.9 a & 2.17 & 6.14 & 6.65 & 6.40 & 18.12 & 6.34 \\
\hline \multicolumn{2}{|c|}{ Grand mean for $(C)$} & $27.9 \mathrm{~b}$ & 29.8 a & & $2.06 \mathrm{~b}$ & $5.83 \mathrm{~b}$ & $6.31 \mathrm{a}$ & $9.87 \mathrm{~b}$ & $6.03 \mathrm{a}$ & \\
\hline \multirow{2}{*}{\multicolumn{2}{|c|}{ Grand mean for $(R)$}} & $5 \mathrm{~kg}$ : & 10 kg: & 15 kg: & $5 \mathrm{~kg}$ : & 10 kg: & 15 kg: & $5 \mathrm{~kg}$ & 10 kg: & 15 kg: \\
\hline & & $28.1 \mathrm{c}$ & $28.9 \mathrm{~b}$ & $29.6 \mathrm{a}$ & 2.07 & 4.93 & 5.12 & 5.02 & 2.02 & 2.08 \\
\hline \multirow{3}{*}{ F-test } & & $\mathrm{M}: \quad * *$ & $\mathrm{R}: * *$ & $\mathrm{C}: * *$ & $\mathrm{M}: \quad \mathrm{NS}$ & R: NS & $\mathrm{C}: *$ & M: NS & $\mathrm{R}: \mathrm{NS}$ & C: $* *$ \\
\hline & & $\mathrm{M} \times \mathrm{R}: \mathrm{NS}$ & $M \times$ & & $\mathrm{M} \times \mathrm{R}: \mathrm{NS}$ & $\mathrm{M} \times \mathrm{C}:$ & NS & $\mathrm{M} \times \mathrm{R}: \mathrm{NS}$ & $M \times$ & C: NS \\
\hline & & $\mathrm{R} \times \mathrm{C}: \mathrm{NS}$ & $\mathrm{M} \times \mathrm{R}$ & $\times \mathrm{C}: \mathrm{NS}$ & $\mathrm{R} \times \mathrm{C}: \mathrm{NS}$ & $\mathrm{M} \times \mathrm{R} \times$ & C: NS & $\mathrm{R} \times \mathrm{C}: \mathrm{NS}$ & $M \times$ & $\mathrm{R} \times \mathrm{C}: \mathrm{NS}$ \\
\hline
\end{tabular}

* Values for control were, 25.1 and $26.2 \mathrm{~g}$ for 100-grain weight; 4.45 and 4.69 ton ha $^{-1}$ for stover yield as well as 3.78 and 4.28 ton ha ${ }^{-1}$ for grain yield under without or with compost, respectively.

* Different lower case letters indicate statistically significant differences between treatments $(\mathrm{P} \leq 0.05)$.

soil and obtained increased physiological and yield of maize. The marked increase in maize yield exhibited by foliar application of micronutrients may be attributed to their crucial roles in many biochemical and physiological processes; photosynthesis, respiration, enzyme activity or involving in growing meristem, maintaining high meristematic activity in the cells of the growing parts, (Siam et al., 2006). Also, addition of such nutrients as foliar application could compensate the soil micronutrients deficiency prevailing in the studied saline soil, thus resulted in an improvement in the nutritive status of maize plants which reflected on the performance of the physiological processes. The obtained results are in accordance with those reported by El-Fouly et al. (2011), Salem and El-Gizawy (2012) and Siam et al. (2012).

Treatment of maize with foliar spray at the high rate combined with compost gave $24.4 \%$ average increase in stover yield and 27.8\% increase in grain yield.

\section{Grain Protein Content and Grain Protein Yield}

Results presented in Table 9 show that the protein content in maize grains increased by application of micronutrients particularly using foliar spray, the effect of rates of micronutrients and compost addition was insignificant. Zeidan et al. (2010) pointed out that foliar application of $\mathrm{Fe}, \mathrm{Mn}$ and $\mathrm{Zn}$ significantly increased protein content of wheat plants. Also, such beneficial effect of compost was actually reflected on increasing maize grain yield and its quality due to the applied organic manure decreased the loss of soil moisture, enhanced soil water retention and the drought resistance of grown plants as well as increased the ability rate of leaves for photosynthetic process, increased the grain filling intensity, and consequently increased the grain weight. These findings are in harmony with those obtained by, Abd El-Hady et al. (2006). 
Table 9. Protein content (\%) and protein yield $\left(\mathrm{kg} \mathrm{ha}^{-1}\right)$ of maize grains

\begin{tabular}{|c|c|c|c|c|c|c|c|}
\hline \multicolumn{2}{|c|}{ Micronutrient addition } & \multicolumn{3}{|c|}{ Protein content } & \multicolumn{3}{|c|}{ Protein yield } \\
\hline & & \multicolumn{6}{|c|}{ Compost application (C) } \\
\hline Method (M) & Rate (R) & Without & With & Mean & Without & With & Mean \\
\hline \multirow{3}{*}{ Coating } & $5 \mathrm{~kg} \mathrm{ha}^{-1}$ & 8.06 & 8.31 & 8.19 & 321.44 & 390.48 & 357.15 \\
\hline & $10 \mathrm{~kg} \mathrm{ha}^{-1}$ & 8.44 & 8.50 & 8.47 & 357.15 & 414.29 & 385.72 \\
\hline & $15 \mathrm{~kg} \mathrm{ha}^{-1}$ & 9.13 & 8.63 & 8.88 & 400.01 & 430.96 & 416.68 \\
\hline \multirow[t]{2}{*}{ Mean } & & 8.54 & 8.48 & $8.52 \mathrm{~b}$ & 359.53 & 359.53 & $411.91 \mathrm{~b}$ \\
\hline & $5 \mathrm{~kg} \mathrm{ha}^{-1}$ & 7.44 & 7.63 & 7.54 & 300.01 & 361.91 & 330.95 \\
\hline \multirow[t]{2}{*}{ Soaking } & $10 \mathrm{~kg} \mathrm{ha}^{-1}$ & 7.69 & 7.81 & 7.75 & 338.10 & 400.01 & 369.06 \\
\hline & $15 \mathrm{~kg} \mathrm{ha}^{-1}$ & 7.88 & 8.06 & 7.97 & 371.44 & 421.44 & 397.63 \\
\hline \multirow[t]{2}{*}{ Mean } & & 7.67 & 7.83 & $7.77 \mathrm{~b}$ & 335.72 & 335.72 & $395.25 \mathrm{~b}$ \\
\hline & 5 kg ha $^{-1}$ & 11.1 & 11.6 & 11.4 & 466.68 & 588.11 & 528.58 \\
\hline \multirow[t]{2}{*}{ Foliar } & $10 \mathrm{~kg} \mathrm{ha}^{-1}$ & 11.4 & 11.9 & 11.7 & 540.49 & 645.25 & 592.87 \\
\hline & 15 kg ha $^{-1}$ & 11.8 & 12.2 & 12.0 & 580.96 & 669.06 & 626.20 \\
\hline \multicolumn{2}{|l|}{ Mean } & 11.4 & 11.9 & $11.7 \mathrm{a}$ & $409.05 \mathrm{~b}$ & 528.58 & $633.35 \mathrm{a}$ \\
\hline \multicolumn{2}{|c|}{ Grand mean for (C) } & 9.22 & 9.40 & & $172 \mathrm{~b}$ & $409.05 \mathrm{~b}$ & \\
\hline \multirow{2}{*}{\multicolumn{2}{|c|}{ Grand mean for (R) }} & $5 \mathrm{~kg}:$ & 10 kg: & 15 kg: & $5 \mathrm{~kg}$ : & 10 kg: & 15 kg: \\
\hline & & 9.02 & 9.29 & 9.62 & 170 & 189 & 201 \\
\hline \multirow{3}{*}{ F-test } & & $\mathrm{M}: \quad * *$ & $\mathrm{R}: \mathrm{NS}$ & $\mathrm{C}: \quad \mathrm{NS}$ & $\mathrm{M}: \quad * *$ & $\mathrm{R}: \quad \mathrm{NS}$ & $\mathrm{C}: \quad * *$ \\
\hline & & $\mathrm{M} \times \mathrm{R}: \mathrm{NS}$ & & $\mathrm{C}: \mathrm{NS}$ & $\mathrm{M} \times \mathrm{R}: \mathrm{N}$ & & $\mathrm{C}: \mathrm{NS}$ \\
\hline & & $\mathrm{R} \times \mathrm{C}: \mathrm{NS}$ & & $\times C$ : NS & $\mathrm{R} \times \mathrm{C}: \mathrm{NS}$ & $M \times 1$ & $\times C:$ NS \\
\hline
\end{tabular}

* Values for control were, 7.81 and $8.06 \%$ for protein content and 295.24 and $345.25 \mathrm{~kg} \mathrm{ha}^{-1}$ for protein yield under without or with compost, respectively.

* Different lower case letters indicate statistically significant differences between treatments $(\mathrm{P} \leq 0.05)$.

Concerning protein content and protein yield, foliar spray was superior to the other methods while, coating was slightly higher than soaking. The highest protein content of $12.2 \%$ and protein yield of $674 \mathrm{~kg} \mathrm{ha}^{-1}$ were recorded in the plants treated with the high foliar spray with compost. The increase percentage over the control was $38.9 \%$ for protein content and 93.8\% for protein yield.

\section{Macronutrients Content and Uptake by Maize Grains}

Data in Tables 10 and 11 illustrate that content and uptake of $\mathrm{N}, \mathrm{P}$ and $\mathrm{K}$ in maize grains were affected significantly by application methods of micronutrients for macronutrients content while, significantly affected by application methods for micronutrients and compost addition for $\mathrm{N}, \mathrm{P}$ and $\mathrm{K}$ uptake by grains. Concerning $\mathrm{N}$-content and uptake, spraying gave the highest values with significant differences with soaking and coating methods which were similar in effect. As for $\mathrm{P}$ and K-contents and uptake, foliar spray and coating methods are equally effective and both were superior to coating method. On the other hand, addition of compost had a significant effect in increasing $\mathrm{N}, \mathrm{P}$ and $\mathrm{K}$ uptake by maize grains. The role of micronutrients in increasing concentrations of macro and micronutrients in maize grains is mainly due to the vital physiological roles in plant cells which promote the uptake of plant nutrients (Abd El-Hady, 2007).

A glance on data is clear that the mixed foliar application of micronutrients $(\mathrm{Fe}+\mathrm{Mn}+\mathrm{Zn})$ jointly with compost application gave the highest values of all studied nutrients content and uptake in maize grains as compared to control. It is well known that, during the decomposition of organic matter, macro and micronutrients are incorporated into the soil matrix, allowing the soil to act as a reservoir of these nutrients. 
These nutrients will be released to become available for uptake by plants. Otherwise, humus which is the final component of organic matter decomposition accumulates in the environmental systems to increase moisture retention and nutrient supply potentials of soils (Suganya and Sivasamy, 2006).

The highest $\mathrm{N}, \mathrm{P}$ and $\mathrm{K}$ uptake by maize grains which were 101.43, 22.07 and $126.19 \mathrm{~kg}$ $\mathrm{ha}^{-1}$, were given by the high foliar spray, respectively; assigned for foliar spray in presence of compost. The lowest comparable values were 55.24, 15.86 and $92.62 \mathrm{~kg} \mathrm{ha}^{-1}$ respectively, were given by the non-treated plants.

\section{Micronutrients Content and Uptake by Maize Grains}

Values of Fe, Mn and Zn uptake by maize grains as affected by application of micronutrients and/or compost were shown in Tables 12 and 13. The content and uptake of Fe, Mn and $\mathrm{Zn}$ followed a pattern similar to that shown by the macronutrient where they increased significantly by the addition of the aforementioned fertilization treatments under with or without addition of compost. Foliar of micronutrients at $15 \mathrm{~kg} \mathrm{ha}^{-1}$ in presence of compost treatment was most effective on increasing content and uptake of $\mathrm{Fe}, \mathrm{Mn}$ and $\mathrm{Zn}$ as compared to the other treatments. The percentages response of $\mathrm{Fe}, \mathrm{Mn}$ and $\mathrm{Zn}$ content and uptake by maize grains over the control were $28.7 \%, 20.5 \%$ and $34.3 \%$ as well as $64.3 \%, 53.2 \%$ and $71.5 \%$, respectively due to the addition treatment of, foliar spray of micronutrients at $15 \mathrm{~kg} \mathrm{ha}^{-1}+$ compost. These findings are in agreement with those reported by Siam et al. (2012) who reported that the application of micronutrients as mixture treatment used as foliar application registered highest content and uptake of micronutrients in maize plant as compared with the other methods. Khalil et al. (2013) reported that foliar spraying of $(\mathrm{Fe}+\mathrm{Mn}+\mathrm{Zn})$ in combination with compost significantly increased $\mathrm{Fe}, \mathrm{Mn}, \mathrm{Zn}$ and $\mathrm{Cu}$ content and uptake by maize grains.

The beneficial responses of increased Fe, Mn and $\mathrm{Zn}$ resulted from adding compost may be attributed to the role of organic sources in improving these micronutrients availability which was likely attributed to several reasons: $i$ ) Releasing of these nutrients through microbial decomposition of organic matter ; ii) Enhancing the chelation of metal ions by fulvic acid, organic legends and/or other organic function groups which may promote the mobility of metal from solid to liquid phase in the soil environment; iii) Lowering the redox statues of iron and manganese, leading to reduction of higher $\mathrm{Fe}^{3+}$ and $\mathrm{Mn}^{4+}$ to $\mathrm{Fe}^{2+}$ and $\mathrm{Mn}^{2+}$ and / or transformation of insoluble chelated forms into more soluble ions. The obtained results are supported by Bakry et al. (2009) and Shaban et al. (2011). The response of maize plants to Fe, Mn and Zn may be due to the important role of these elements in enzymes activation and hormones regulation, in metabolism of carbohydrate, proteins and auxins and also in multiple processes, development, division and differentiation of cells. In addition, $\mathrm{Fe}$ is characteristics for its ability to undergo oxidation-reduction reaction and to form a component of chlorophyll. Zn also plays an essential role in the synthetase and metabolism of tryptophan. Mn influences directly the indole acetic acid balance in plants, responsible for plant height (RÖmheld and Marchner, 2006).

Moreover, the superior effect of the mixture treatment may be due to the suitable balance between the aforementioned micronutrients, which enable the plants to grow well and to absorb more quantities of macro and micronutrients.

The statistical data in Tables 12 and 13 indicate that foliar spray showed significant superiority regarding $\mathrm{Fe}, \mathrm{Mn}, \mathrm{Zn}$-contents and Fe-uptake values by maize grains comparing with coating and soaking methods. Also, coating, though was slightly superior to soaking, such superiority was statistically significant for Fe and Zn-content. Spray and soaking were equally effective and both were superior to coating regarding Mn-uptake while, spraying method was superior to the other methods. 
Table 12. Fe, Mn and $\mathrm{Zn}$ contents ( $\mathrm{mg} \mathrm{kg}^{-1}$ ) of maize grains as affected by treatments

\begin{tabular}{|c|c|c|c|c|c|c|c|c|c|c|}
\hline \multirow{2}{*}{\multicolumn{2}{|c|}{ Micronutrient addition }} & \multicolumn{3}{|c|}{ Fe-content } & \multicolumn{3}{|c|}{ Mn-content } & \multicolumn{3}{|c|}{ Zn-content } \\
\hline & & \multicolumn{9}{|c|}{ Compost application (C) } \\
\hline \multirow[t]{2}{*}{$\begin{array}{l}\text { Method (M) } \\
\end{array}$} & Rate (R) & Without & With & Mean & Without & With & Mean & Without & With & Mean \\
\hline & $5 \mathrm{~kg} \mathrm{ha}^{-1}$ & 98.3 & 113 & 106 & 80.2 & 84.6 & 82.4 & 24.6 & 25.4 & 25.0 \\
\hline \multirow[t]{2}{*}{ Coating } & $10 \mathrm{~kg} \mathrm{ha}^{-1}$ & 105 & 121 & 113 & 84.6 & 86.1 & 85.4 & 24.9 & 25.9 & 25.4 \\
\hline & $15 \mathrm{~kg} \mathrm{ha}^{-1}$ & 111 & 127 & 119 & 88.3 & 89.1 & 88.7 & 25.0 & 26.2 & 25.6 \\
\hline \multirow[t]{2}{*}{ Mean } & & 105 & 120 & $113 \mathrm{~b}$ & 84.4 & 86.6 & $85.5 \mathrm{c}$ & 24.8 & 25.8 & $25.3 \mathrm{~b}$ \\
\hline & $5 \mathrm{~kg} \mathrm{ha}^{-1}$ & 88.3 & 90.1 & 89.2 & 75.3 & 76.5 & 75.9 & 18.8 & 23.1 & 21.0 \\
\hline \multirow[t]{2}{*}{ Soaking } & $10 \mathrm{~kg} \mathrm{ha}^{-1}$ & 92.4 & 93.2 & 92.8 & 79.3 & 80.2 & 79.8 & 22.2 & 22.9 & 22.6 \\
\hline & $15 \mathrm{~kg} \mathrm{ha}^{-1}$ & 93.5 & 98.7 & 96.1 & 83.1 & 84.4 & 83.8 & 24.6 & 24.9 & 24.8 \\
\hline \multirow[t]{2}{*}{ Mean } & & 91.4 & 94.0 & 92.7 c & 79.2 & 80.4 & 79.8 b & 21.9 & 23.6 & $22.8 \mathrm{c}$ \\
\hline & $5 \mathrm{~kg} \mathrm{ha}^{-1}$ & 116 & 118 & 117 & 85.6 & 88.3 & 87.0 & 25.7 & 26.0 & 25.9 \\
\hline \multirow{2}{*}{ Foliar } & $10 \mathrm{~kg} \mathrm{ha}^{-1}$ & 122 & 123 & 123 & 89.5 & 91.2 & 90.4 & 28.3 & 28.7 & 28.5 \\
\hline & $15 \mathrm{~kg} \mathrm{ha}^{-1}$ & 128 & 130 & 129 & 92.1 & 95.4 & 93.8 & 28.8 & 29.0 & 28.9 \\
\hline \multicolumn{2}{|l|}{ Mean } & 122 & 124 & 123 a & 89.1 & 91.6 & $90.4 \mathrm{a}$ & 27.6 & 27.9 & $27.8 \mathrm{a}$ \\
\hline \multicolumn{2}{|c|}{ Grand mean for $(C)$} & $106 \mathrm{~b}$ & 113 a & & $84.2 \mathrm{~b}$ & $86.2 \mathrm{a}$ & & $24.8 \mathrm{~b}$ & $25.8 \mathrm{a}$ & \\
\hline \multirow{2}{*}{\multicolumn{2}{|c|}{ Grand mean for (R) }} & $5 \mathrm{~kg}:$ & 10 kg: & $15 \mathrm{~kg}:$ & $5 \mathrm{~kg}:$ & 10 kg: & 15 kg: & 5 kg: & $10 \mathrm{~kg}:$ & 15 kg: \\
\hline & & $104 \mathrm{c}$ & $109 \mathrm{~b}$ & $115 \mathrm{a}$ & $81.8 \mathrm{c}$ & $85.2 \mathrm{~b}$ & 88.7 a & $23.9 \mathrm{c}$ & $25.5 \mathrm{~b}$ & $26.4 \mathrm{a}$ \\
\hline \multirow{3}{*}{ F-test } & & M: $\quad * *$ & $\mathrm{R}: * *$ & C: $* *$ & M: ** & $\mathrm{R}: * *$ & C: ** & M: ** & $\mathrm{R}: * *$ & C: $* *$ \\
\hline & & $\mathrm{M} \times \mathrm{R}: * *$ & & $\times \mathrm{C}: * *$ & $\mathrm{M} \times \mathrm{R}: \mathrm{NS}$ & IS $\quad \mathrm{M} \times$ & $\mathrm{C}: \mathrm{NS}$ & $\mathrm{M} \times \mathrm{R}:$ * & & $\times \mathrm{C}: \mathrm{NS}$ \\
\hline & & $\mathrm{R} \times \mathrm{C}: \mathrm{NS}$ & $\mathrm{M} \times \mathrm{F}$ & $2 \times C: N S$ & $\mathrm{R} \times \mathrm{C}: \mathrm{NS}$ & $S \quad M \times R$ & $2 \times C: N S$ & $\mathrm{R} \times \mathrm{C}: \mathrm{N}$ & $M$ & $\times \mathrm{R} \times \mathrm{C}: *$ \\
\hline
\end{tabular}

Table 13. Fe, Mn and Zn uptake ( $\mathrm{g} \mathrm{ha}^{-1}$ ) by maize grains as affected by treatments

\begin{tabular}{|c|c|c|c|c|c|c|c|c|c|c|}
\hline \multicolumn{2}{|c|}{ Micronutrient addition } & \multicolumn{3}{|c|}{ Fe-uptake } & \multicolumn{3}{|c|}{ Mn-uptake } & \multicolumn{3}{|c|}{ Zn-uptake } \\
\hline & & \multicolumn{9}{|c|}{ Compost application (C) } \\
\hline \multicolumn{2}{|c|}{ Method (M) Rate (R) } & Without & With & Mean & Without & With & Mean & Without & With & Mean \\
\hline \multirow{3}{*}{ Coating } & $5 \mathrm{~kg} \mathrm{ha}^{-1}$ & 390.48 & 530.96 & 461.91 & 319.05 & 397.63 & 359.53 & 97.86 & 119.05 & 108.57 \\
\hline & $10 \mathrm{~kg} \mathrm{ha}^{-1}$ & 445.25 & 590.49 & 519.06 & 359.53 & 421.44 & 390.48 & 105.48 & 126.43 & 115.95 \\
\hline & $15 \mathrm{~kg} \mathrm{ha}^{-1}$ & 485.72 & 635.73 & 561.92 & 385.72 & 445.25 & 416.68 & 109.53 & 130.96 & 120.00 \\
\hline \multirow[t]{2}{*}{ Mean } & & 440.49 & 585.73 & $511.92 \mathrm{~b}$ & 354.77 & 421.44 & $388.10 \mathrm{a}$ & 104.29 & 125.48 & $114.76 \mathrm{~b}$ \\
\hline & $5 \mathrm{~kg} \mathrm{ha}^{-1}$ & 354.77 & 426.20 & 390.48 & 302.39 & 361.91 & 333.34 & 75.72 & 109.53 & 92.62 \\
\hline \multirow[t]{2}{*}{ Soaking } & $10 \mathrm{~kg} \mathrm{ha}^{-1}$ & 407.15 & 476.20 & 442.87 & 350.01 & 409.53 & 380.96 & 97.86 & 117.15 & 107.62 \\
\hline & $15 \mathrm{~kg} \mathrm{ha}^{-1}$ & 440.49 & 514.30 & 478.58 & 392.87 & 440.49 & 416.68 & 115.95 & 129.76 & 122.86 \\
\hline \multirow[t]{2}{*}{ Mean } & & 400.01 & 471.44 & $438.10 \mathrm{c}$ & 347.63 & 404.77 & $376.20 \mathrm{~b}$ & 96.43 & 118.81 & $107.38 \mathrm{~b}$ \\
\hline & $5 \mathrm{~kg} \mathrm{ha}^{-1}$ & 488.11 & 597.63 & 542.87 & 361.91 & 447.63 & 404.77 & 108.34 & 131.91 & 120.24 \\
\hline \multirow[t]{2}{*}{ Foliar } & $10 \mathrm{~kg} \mathrm{ha}^{-1}$ & 578.58 & 666.68 & 623.82 & 423.82 & 495.25 & 459.53 & 134.05 & 155.72 & 145.00 \\
\hline & $15 \mathrm{~kg} \mathrm{ha}^{-1}$ & 630.97 & 711.92 & 671.44 & 454.77 & 521.44 & 488.11 & 141.91 & 158.81 & 150.48 \\
\hline \multicolumn{2}{|l|}{ Mean } & 566.68 & 659.54 & $614.30 \mathrm{a}$ & 414.29 & 488.11 & $450.01 \mathrm{a}$ & 128.10 & 148.81 & $138.57 \mathrm{a}$ \\
\hline \multicolumn{2}{|c|}{ Grand mean for $(C)$} & 469.06 & 571.44 & & 371.44 & 438.10 & & 109.53 & 130.96 & \\
\hline \multirow{2}{*}{\multicolumn{2}{|c|}{ Grand mean for $(R)$}} & 5 kg: & 10 kg: & 15 kg: & 5 kg: & 10 kg: & 15 kg: & 5 kg: & $10 \mathrm{~kg}:$ & 15 kg: \\
\hline & & $464.30 \mathrm{~b}$ & $528.58 \mathrm{a}$ & $569.06 a$ & 364.29b & $409.53 \mathrm{~b}$ & $440.49 a$ & $107.15 \mathrm{~b}$ & $122.86 \mathrm{a}$ & $131.19 \mathrm{a}$ \\
\hline \multirow{3}{*}{\multicolumn{2}{|c|}{ F-test }} & $\mathrm{M}: \quad * *$ & $\mathrm{R}: \quad * *$ & $\mathrm{C}: * *$ & $\mathrm{M}: \quad * *$ & $\mathrm{R}: \quad * *$ & $\mathrm{C}: \quad * *$ & $\mathrm{M}: \quad * *$ & $* *$ & $\mathrm{C}: \quad * *$ \\
\hline & & $\mathrm{M} \times \mathrm{R}: \mathrm{N}$ & & $\times \mathrm{C}: \mathrm{NS}$ & $\mathrm{M} \times \mathrm{R}: \mathrm{N}$ & & C: NS & $\mathrm{M} \times \mathrm{R}: \mathrm{N}$ & IS & $\times \mathrm{C}: \mathrm{NS}$ \\
\hline & & $\mathrm{R} \times \mathrm{C}: \mathrm{N}$ & $\mathrm{M} \times \mathrm{R}$ & $\mathrm{R} \times \mathrm{C}: \mathrm{NS}$ & $\mathrm{R} \times \mathrm{C}: \mathrm{N}$ & $M>$ & $\times \mathrm{C}: \mathrm{NS}$ & $\mathrm{R} \times \mathrm{C}: \mathrm{N}$ & & NS \\
\hline
\end{tabular}

\footnotetext{
* Values for control were 350 and $433 \mathrm{~g} \mathrm{~kg}^{-1}$ for Fe-uptake; 297 and $340 \mathrm{~g} \mathrm{~kg}^{-1}$ for Mn-uptake as well as 78.09 and $92.62 \mathrm{~g} \mathrm{~kg}^{-1}$ for Zn-uptake under with or without compost, respectively.

* Different lower case letters indicate statistically significant differences between treatments $(\mathrm{P} \leq 0.05)$.
} 


\section{Conclusion}

Based on the results obtained, it might be concluded that application of compost in combination with foliar application of micronutrients $(\mathrm{Fe}+\mathrm{Mn}+\mathrm{Zn})$ had the highest effect on all quantities of yield characteristics. Foliar application of micronutrients could be useful for improving the nutrient status, physiological performance of maize plants which led to an increase in concentration and uptake of macro and micronutrients by grains under saline soil conditions. These desirable effects could be consequences of their influences on improving the mineral nutrition status and physiological performance of maize plants that assisted them to tolerate the unfavorable saline conditions, characterized this area.

\section{REFERENCES}

Abd El-Hady, M.A., M.S. El Habba, N.A. Noureldin and M.F. Hamed (2006). Response of wheat productivity and quality to bioorganic and inorganic fertilizers. Annals Agric. Sci., Ain Shams Univ., 51 (1): 103-111.

Abd El-Hady, B.A. (2007). Effect of zinc application on growth and nutrient uptake of barley plant irrigated with saline water. J. Appl. Sci. Res., 3 (6): 431 - 436.

Akram, M., M.Y. Ashraf, E.A. Waraich, M. Hussain, N. Hussain and A.R. Mallahi (2010). Performance of autumn planted maize (Zea mays L.) hybrids at various nitrogen levels under salt affected soils. Soil Environ., 29: 23-32

AOAC (1990). Official Methods of Analysis of the Association of Official Analytical Chemists. $15^{\text {th }}$ Ed., 7 Washington, DC. USA.

Bakry, M.A., Y.R. Soliman and S.A. Moussa (2009). Importance micronutrients, organic manure and bio-fertilizer for improving maize yield and its components grown in desert sandy soil. Res. J. Agric. Bio. Sci., 5 (1): $16-23$.
Bassiony, H.M. and Kh.A. Shaban (2010). Economic analysis for the efficiency use of mineral and bio-fertilizers on saline soil. Zagazig, J. Agric. Res., 37 (5): 1313- 1330.

Bhandari, A.L., J.K. Ladha, H. Pathak, A.T. Padre, D. Dawe and R.K. Gupta (2002). Yield and soil nutrient changes in a longterm rice-wheat rotation in India. Soil Sci. Soc. Am. J., 66: 162-170.

Brunner, P.H. and H.R. Wasmer (1978). Methods of analysis of sewage sludge solid wastes and compost. W.H.O. International Reference Center for Wastes Disposal (H8600), Dulendr of Switzerland.

Chapman, H.D. and P.F. Pratt (1961). Method of Plant Analysis. Method of Analysis for Soil, Plant and Water. Chapman Pub., Riverside, California, USA.

El-Bordiny, M.M. and C.Y. El-Dewiny (2008). Effect of some salt affected soil properties on micronutrients availability. J. Appl. Sci. Res., 4 (11): 1569- 1573.

El-Fouly, M.M., Z.M. Mobarak and Z.A. Salama (2011). Micronutrients (Fe, Mn and Zn) foliar spray for increasing salinity tolerance in wheat Triticium aestivium L. African J. Plant Sci., 5 (5): 314 - 322.

El-Galad, M.A., D.A. Sayed and R.M. El-Shal (2013). Effect of humic acid and compost applied alone or in combination with Sulphur on soil fertility and Faba bean productivity under saline soil conditions. J. Soil Sci. and Eng., Mansoura Univ., 4 (10): 1139 - 1157.

El-Gedwy, E.M.M., R.M. Gomaa and S.A.H. Allam (2012). Maize yield as affected by periods of weed control and plant densities. Ph. D. Thesis, Fac. Agric., Benha Univ., Egypt.

Ewees, M.S.A. and A.A.A. Abdel-Hafeez (2010). Response of maize grain yield to a partial substitution of $\mathrm{N}$-mineral by applying organic manure, bio-inoculation and elemental sulphur as an alternative strategy to avoid the possible chemical pollution. Egypt. J. Soil Sci., 50 (1): 141 - 166. 
FAO (2003). Food energy-methods of analysis and conversion factors. Report of a Technical Workshop. Food and Nut. Paper, 77 :7 - 11.

Gomez, A.K. and A.A. Gomez (1984). Statistical Procedures for Agricultural Research. $2^{\text {nd }}$ Ed. John Wiley and Sons, New York.

Harris, A., G. Rashid, M. Miraj, M. Arif and H. Shah (2007). On-farm seed priming with zinc sulphate solution-A cost-effective way to increase the maize yields of resource-poor farmers. Field Crops Res., 110: 119 - 127.

Helmy, A.M. and Kh.A. Shaban (2008). Response of peanuts to $\mathrm{K}$ fertilization and foliar spraying with zinc and boron under sandy soil conditions. Zagazig J. Agric. Res., 35(2): $343-362$

Hussain, M., H.W. Park, M. Farooq, K. Jabran and D.J. Lee (2013). Morphological and physiological basis of salt resistance in different rice genotypes. Int. J. Agric. Biol., 15: $113-118$

Hythum, M.S. and Kh.B.E. Nasser (2012). Importance of micronutrients and its application methods for improving maize (Zea mays L.) yield grown in clayey soil. Am.-Eurasian J. Agric. Environ. Sci., 12 (7): $954-959$.

Jackson, M.L. (1958). Soil Chemical Analysis. Prentic-HallIns., Engle Wood Cliffs, U.S.A.

Kanwal, S., M.R. Rahmatullah and R. Ahmed (2010). Zinc partitioning in maize grain after soil fertilization with zinc sulphate. Int. J. Agric. Biol., 12: 299 - 302.

Khalil, Z.M., M.A.S. Abdel-Wahab and H.M.H. Amera (2013). The effective role of compost, humic substances and some micronutrients for maize grown under saline soil conditions. Egypt. J. Appl. Sci., 28 (12): 432 - 451.

Malakouti, M.J. (2008). The effect of micronutrients in ensuring efficient use of macronutrients. Tur. J. Agric. For., 32: 215 - 220.

Nasef, M.A., Kh.A. Shaban and A.F. Abdel Hameed (2009). Effect of compost and biofertilizer application on some chemical soil properties and rice productivity under saline soil condition. J. Agric. Mansoura Univ., 34 (4): 2609- 2623.

Page, C.A., D.D. Evans, J.L. White, L.E. Ensiminger and F.E. Clark (1982). Methods of Soil Analysis. Am. Soc. Agron. Inc., Ser. 9 in Agron. Madison, Wisconsin.

Potarzycki, J. and W. Grzebisz (2009). Effect of zinc foliar application on grain yield of maize and its yielding components. Plant Soil Environ., 55 (12): 519 - 527.

Rashed, F.M., H.H. Kesba, W.D. Saleh and M.A. Moselhy (2011). Impact of rice straw compost on microbial population plant growth nutrient uptake and root-knot nematode under greenhouse conditions. Afr. J. Agric. Res., 6: 1188 - 1203.

RÖmheld, V. and H. Marchner (2006). Function of micronutrients in plants. In "Micronutrients in Agriculture". Published by Soil Sci. Soc. Am. Inc., Madison, Wisconsim, USA., 311.

Salem, H.M. and N.Kh.B. El-Gizawy (2012). Importance of micronutrients and its application methods for improving maize (Zea mays L.) yield grown in clayey soil. Am.-Eurasian J. Agric. Environ. Sci., 12 (7): $954-959$.

Sarwar, G., H. Schmeisky, M.A. Tahir, Y. Lftikhar and N.U. Sabah (2010). Application of greencompost for improvement in soil chemical properties and fertility status. J. Animal Plant Sci., 20 (4): 258 - 260.

Seadh, S.E., M.I. El-Abady, A.M. El-Ghamry and S. Farouk (2009). Influence of micronutrients foliar application and nitrogen fertilization on wheat yield and quality of grain and seed. J. Bio. Sci., 9 (8): 851 - 858.

Shaban, Kh.A., G.A. Mona and M.E. Seham (2011). Evaluation of organic farm and compost combined with urea fertilizers on fertility and maize productivity in newly reclaimed. Research J. Agric. Biol. Sci., 7(5): $388-397$.

Siam, H.S., Kh.S. Moursy and H.I. El-Aila (2006). Effect of different sources and methods of application of iron on improvement of growth and nutrient uptake 
by Sudan grass. Egypt. J. Appl. Sci., 21 (11B): $772-789$.

Siam, H.S., M.G. Abd El-Kader and M.S. Abd El-Fattah (2012). Effect of ammonia gas and some micronutrients on maize plants (Zea mays) I- plant growth and mineral uptake. Aust. J. Basic Appl. Sci., 6 (3): 462 - 473.

Suganya, S. and R. Sivasamy (2006). Moisture retention and cation exchange capacity of sandy soils as influenced by soil additivies. J. Appl. Sci. Res., 2: 949 - 951.

Taha, M.B., H.S. Said and Sh.E.B. Ibrahim (2010). Effect of gypsum and farmyard manure on the productivity of wheat grown on a clayey soil. Egypt. J. Appl. Sci., 25 (5): $297-307$.

Wenhui, Z., G. Ting, W. Wei, Z. Bin, L. Xiangui, H. Qianru and S. Weishou (2010). The effect of mineral fertilizer and organic manure on microbial community and diversity. Plant and Soil, 326: 511 - 522.

Yadvinder, S., B. Singh, J.K. Ladha, C.S. Khind, R.K. Gupta, O.P. Meelu and E. Pasuquin (2004). Long-term effects of organic inputs on yield and soil fertility in rice-wheat rotation. Soil Sci. Soc. Am. J., 68: $845-853$

Zafar-ul-Hye, M., M.F. Hafiz, A.Z. Zahir, H. Mubshar and H. Amjad (2014). Application of ACC-deaminase containing rhizobacteria with fertilizer improves maize production under drought and salinity stress. Int. J. Agric. Biol., 16 (3) : 591 - 596.

Zeidan, M.S., M.F. Mohamed and H.A. Hamouda (2010). Effect of foliar fertilization of $\mathrm{Fe}, \mathrm{Mn}$ and $\mathrm{Zn}$ on wheat yield and quality in low sandy soils fertility. World J. Agric. Sci., 6 (6): 696 - 699. 
تأثير بعض طرق الإضافة المختلفة (الرش ، التظليف و النقع) للعناصر الصغرى بمعدلات مختلفة

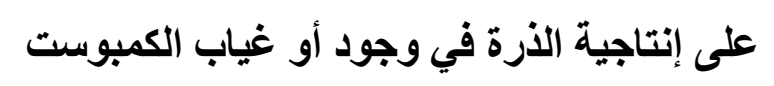

$$
\begin{aligned}
& \text { محمد محمود نبيل' - سامية حسن عثماوى ` ـ سارة السيد السبي فودة' }
\end{aligned}
$$

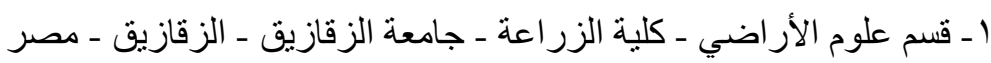

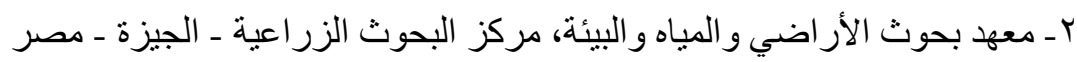

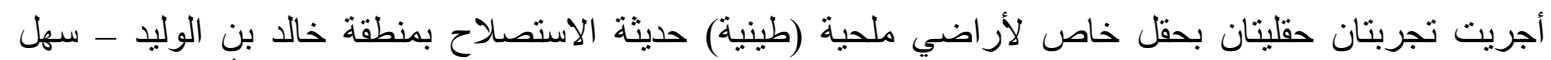

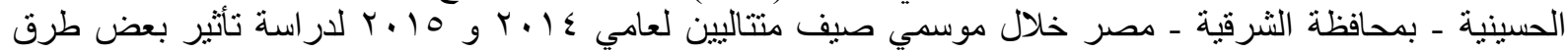

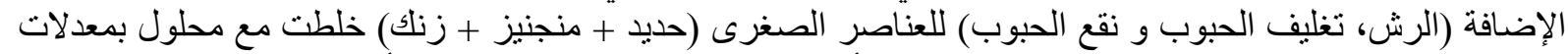

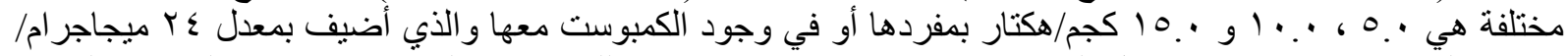

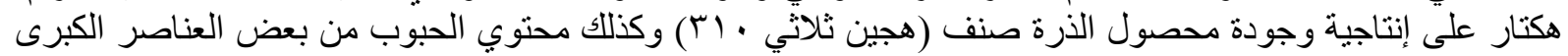

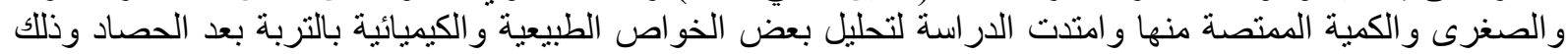

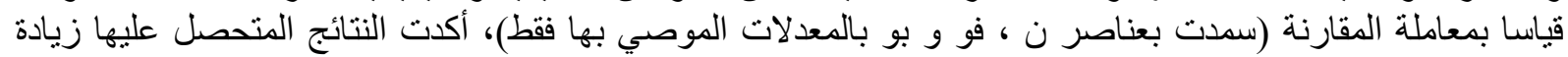

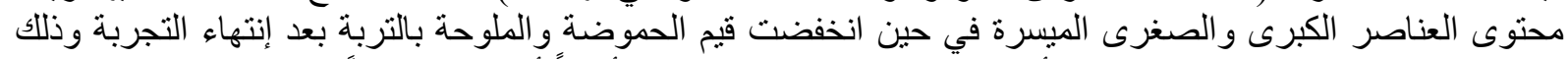

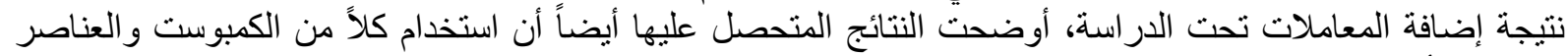

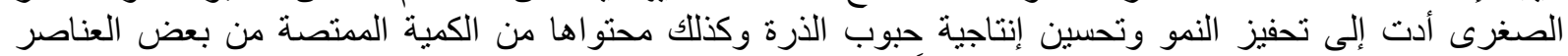

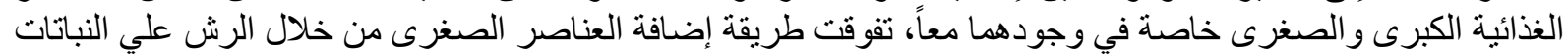

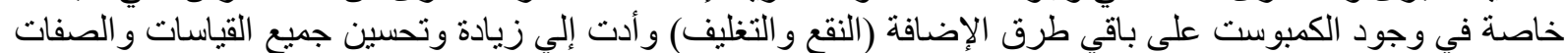

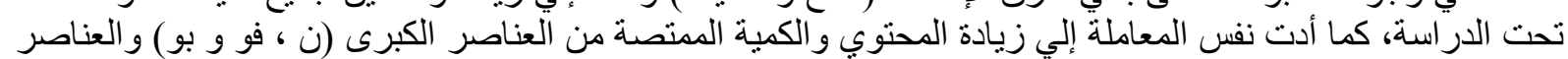

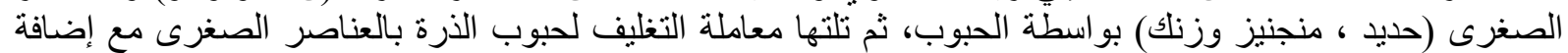

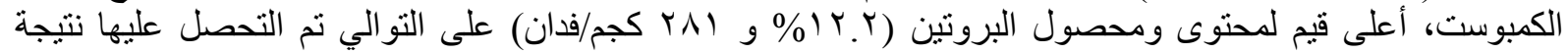
المعاملة الرش بالعناصر الصغرى في في وجود الكمبوست. 